\title{
PERILAKU BAHASA MENYIMPANG PADA PESERTA DIDIK
}

\author{
Ade Kusmana \\ Pendidikan Bahasa dan Seni (PBS) FKIP Universitas Jambi \\ Jl. Jambi Muara Bulian Mendalo Darat Jambi \\ Email: dr.akusmana@gmail.com
}

\begin{abstract}
Abstrak:
Bahasa merupakan salah satu parameter dalam perkembangan anak. Kemampuan berbicara dan berbahasa melibatkan perkembangan kognitif, sensorimotor, psikologis, emosi, dan lingkungan sekitar anak. Ketika prinsip-prinsip koordinasi antara akal pikiran dan mekanisme fisiologis tidak berfungsi secara sempurna maka terjadilah penyimpangan bahasa. Kategori utama penyimpangan bahasa dalam hubungannya dengan lingkungan rumah adalah (1) yang terbentuk sebagai bagian dari perkembangan normal bahasa anak, dan (2) sebagai akibat dari gangguan psychogenic atau physiogenic. Perilaku bahasa menyimpang menjadi signifikan dalam kehidupan sekolah anak-anak. Segala bentuk kelainan berbicara dan seluruh tingkat kelainannya tidak akan terpisahkan dari kelas. Sehingga masalah kelainan semestinya tidak terlibat dalam situasi kelas.
\end{abstract}

\begin{abstract}
Abstrak
Language is one of the parameters in young learners' development. The ability in speech and language involve cognitive, sensorimotor, psychological, emotional and environmental developments around the children. When the principles of coordination between the mind and physiological mechanism is not working properly, language deviation will happen. The main categories of language deviation in relation to home environment are: (1) as a part of the normal development of children's language, and (2) as a result of psychogenic or physiogenic disorders. Language behavior deviation becomes significant in the lives of school children. All forms of disorders of speech and all levels of disorder will not be separated from the classroom so the disorder problem should not be involved in the classroom situation.
\end{abstract}

Kata Kunci:

Prilaku, menyimpang, bahasa

BAHASA merupakan salah satu parameter dalam perkembangan anak. Kemampuan berbicara dan berbahasa melibatkan perkembangan kognitif, sensorimotor, psikologis, emosi dan lingkungan sekitar anak. Kemampuan bahasa pada umumnya dapat dibedakan atas kemampuan reseptif dan produktif (mendengar dan memahami) dan kemampuan ekspresif (berbicara/menulis). Kemampuan berbicara lebih dapat dinilai dari kemampuan lainnya sehingga pembahasan mengenai kemampuan bahasa lebih sering dikaitkan dengan kemampuan berbicara. ${ }^{1}$ Kemahiran dalam berbahasa dan berbicara dipengaruhi oleh faktor intrinsik (dari anak) dan faktor ekstrinsik (dari lingkungan). Faktor intrinsik yaitu kondisi pembawaan sejak lahir termasuk fisiologi dari organ yang terlibat dalam kemampuan berbahasa dan berbicara. Sementara itu faktor ekstrinsik, stimulus yang ada di sekeliling anak terutama perkataan yang didengar atau ditujukan kepada si anak, juga sangat menentukan perkembangan kemampuan berbahasa anak. 
Gangguan berbicara adalah salah satu penyebab gangguan perkembangan yang paling sering ditemukan pada anak. Keterlambatan bicara adalah keluhan utama yang sering dicemaskan dan dikeluhkan orang tua dan gejala ini pula merupakan masalah dalam proses pembelajaran di kelas. Gangguan ini semakin hari tampak semakin meningkat pesat. Dari penelitian didapatkan bahwa gangguan bahasa dan berbicara terjadi $1 \%$ sampai $32 \%$ dari populasi normal dan sebanyak $60 \%$ dari kasus yang ditemukan terjadi secara spontan pada anak berumur di bawah 3 tahun. ${ }^{2}$

Gangguan berbahasa dan berbicara harus menjadi prioritas bagi orang tua secara dini agar penyebabnya dapat segera dicari, sehingga pengobatan dan pemulihannya dapat diberikan sesegera mungkin karena akan sangat mempengaruhi perkembangan anak di masa depan. Gangguan dalam perkembangan bahasa dan artikulasi, selain menyebabkan hambatan dalam bidang akademik, akan menyebabkan pula hambatan dalam bidang hubungan sosial, yang kemudian dapat menimbulkan berbagai macam tingkah laku, seperti membolos, minat belajar kurang, dan berbagai macam tingkah laku antisosial. Tidak jarang kepribadian anak ikut terpengaruh misalnya anak mulai merasa rendah diri atau minder dan sering cemas menghadapi lingkungannya.

Tulisan ini membahas perilaku bahasa menyimpang (deviant language behaviour) yang disebabkan oleh faktor psikologis atau fisiologis dan hubungan permasalahan ini dengan lingkungan rumah dan kaitannya pengajaran bahasa di kelas.

\section{LATAR BELAKANG PSIKOLOGIS DAN FISIOLOGIS}

Kemampuan berbahasa seseorang dipengaruhi oleh faktor kejiwaan (psikis) dan faktor fisik (organ-organ artikulai dan otak). Bila seseorang mengalami gangguan psikis atau kelainan fisik (gangguan pada organ-organ artikulasi dan otak) maka dapat dipastikan tidak akan menghasilkan bahasa yang normal. Sebagaimana dikatakan Mukalel bahwa bahasa merupakan hasil dari koordinasi fungsi akal pikiran manusia dan mekanisme fisiologis. ${ }^{3}$ Ketika prinsip-prinsip koordinasi antara akal pikiran dan mekanisme fisiologis tidak berfungsi secara sempurna maka terjadilah penyimpangan dalam bahasa (atau disebut juga gangguan bicara dan patologi bahasa). Bahasa menyimpang dalam bentuk abnormalitas bahasa menurut Mukalel dapat disebabkan oleh: (1) gangguan fisiologis (2) gangguan mental, (3) gangguan fisiologis yang disebabkan oleh abnormalitas mental, dan (4) gangguan mental yang disebabkan oleh abnormalitas fisiologis. ${ }^{4}$ Pendapat Mukalel ini hampir sama dengan Bayles \& Kaszniak yang menyatakan bahwa gangguan atau kelainan berbicara pada seseorang disebabkan oleh faktor fisik dan psikis; akan tetapi faktor fisik lebih dominan daripada faktor psikis. ${ }^{5}$ Yang dimaksud dengan faktor fisik ini adalah otak dan alat-alat ujaran, sedangkan faktor psikis adalah segala sesuatu yang berhubungan dengan gangguan kejiwaan (misalnya, trauma, perasaan tertekan [stress] atau rasa takut). Dalam sumber lain, Caplan menulis bahwa kelainan bahasa disebabkan oleh kelainan pada otak dan organ-organ yang berfungsi sebagai alat ujaran. ${ }^{6}$ Caplan tidak menyinggung masalah kejiwaan sebagai penyebab penyimpangan dalam berbahasa. 
Bahasa pada manusia dihasilkan melalui mekanisme yang rumit, dan suara yang dikeluarkan oleh setiap orang memiliki keunikan masing-masing. Warna suara antara individu akan berbeda dengan suara individu lainnya. Perbedaan ini terjadi karena struktur fisiologis alat-alat ujaran yang dimiliki tiap individu berbeda dengan individu lainnya. ${ }^{7}$

Pusat mekanisme fisiologi aktivitas bahasa terdiri atas struktur neurologis dengan bagian-bagiannya (1) sistem saraf pusat, (2) sistem saraf peripheral, dan (3) sistem saraf symphathetic. Sistem saraf pusat terdiri atas otak dan urat saraf tulang belakang; sistem saraf peripheral terdiri atas saraf luar dan saraf belakang yang menghubungkan sistem pusat dengan mekanisme peripheral. Mekanisme peripheral ini mencakup (1) organ-organ pembentuk suara untuk produksi bahasa, dan (2) organ-organ pendengaran untuk pemerolehan bahasa. Untuk dapat berbicara maka melibatkan beberapa aktivitas. ${ }^{8}$ Untuk bisa menghasilkan ujaran maka yang terjadi adalah mencakup manipulasi diafragma, paru-paru, otot-otot dada, pita suara, mulut, lidah, gigi, dan bibir. Oleh karena itu, jika ada kelainan pada alat-alat ini maka kualitas ujaran akan terganggu. Pita suara memiliki dua membran yang terbentang di bagian dalam pangkal tenggorokan. Fungsi pita suara adalah untuk menghasilkan 'suara' yang dipengaruhi oleh getaran dua lipatan dalam pangkal tenggorokan sehingga suara dapat didengar. Kurang aktifnya pita suara menyebabkan ujaran kurang dapat didengar. Bicara akan berubah menjadi bisikan jika pita suara tidak aktif. Fungsi ujaran akan terhambat jika pita suara tidak aktif. Kadang-kadang karena gangguan penyakit tertentu pada tenggorokan yang memengaruhi pita suara menyebabkan ketidakmampuan untuk menghasilkan suara terkecuali bisikan.

Selain paru-paru, pipa udara dan pita suara hampir setiap bagian dari mulut membantu produksi bahasa dalam cara yang terkoordinasi. Lidah dengan bagian-bagiannya: ujung, tengah, depan, belakang memegang peranan utama dalam pembentukan bunyi-bunyi vokal dan konsonan. Alveolar, langit-langit keras dan langit-langit lunak memegang peranan utama dalam pembentukan konsonan ketika lidah menyentuh posisi ini pada bagian atas dari mulut. Anak tekak berfungsi untuk mengendalikan pembentukan bunyi-bunyi nasal. Gigi, gusi bagian atas dan lidah bagian bawah merupakan mekanisme penting dalam pembentukan bunyi (komponen utama bahasa lisan).

Telinga dengan struktur internalnya membentuk organ pendengaran untuk penerimaan bahasa. Telinga berfungsi secara mekanis yang khas. Gelombang suara masuk melalui saluran luar dan menyentuh apa yang disebut tympanic membrane (gendang telinga). Getaran membran ini mengaktifkan hammer yang tersambung dengannya dan selanjutnya anvil dan stirrup. Stirrup menggentarkan oval window. Pergerakan oval window mengirimkan gelombang ke saluran vestibuler dan saluran tympanic, keduanya berisi cairan, dan selanjutnya ke cochlea. Dari cochlea getaran suara alam frekuensi tinggi dan rendah diteruskan ke kumpulan membran saraf; selanjutnya ransangan sampai pada cortex otak. Tiap telinga dihubungkan dengan dua sisi cortex. 
Organ pendengaran manusia memegang peranan penting dalam aktivitas bahasa sehingga cacat (abnormalitas) pada organ pendengaran akan menimbulkan masalah dalam pemerolehan bahasa. Telinga merupakan organ yang sangat sensitif yang dapat membantu perilaku bahasa sehingga kerusakan pada organ ini akan menimbulkan gangguan pada perilaku bahasa pada manusia.

Caplan sependapat dengan Dingwall bahwa perilaku bahasa menyimpang merupakan akibat dari kelainan bawaan (sejak lahir), yang bisa bersifat permanen, atau sementara. ${ }^{9}$ Akan tetapi Goldstein mengatakan bahwa perilaku bahasa menyimpang di samping sebagai faktor bawaan sejak lahir, juga disebabkan oleh penyakit tertentu setelah memasuki usia kanak-kanak atau dewasa. ${ }^{10}$ Sementara itu, akal pikiran menurut Mukalel, sebagai prinsip koordinat bahasa, dapat juga menyebabkan perilaku bahasa menyimpang. ${ }^{11}$ Kelainan akal pikiran sering mengakibatkan kekacauan dan penyimpangan perilaku individu. Kelainan psikologi, menurut Mukalel, pada umumnya disebabkan oleh perkembangan yang cacat dan situasi tertekan (stres) yang berlebihan. Perkembangan yang cacat mungkin terjadi secara biologis, psikologis, dan sosiologis. Demikian juga situasi tertekan mungkin terjadi secara biologis, psikologis, dan sosiologis. 12

\section{MAKNA PERILAKU BAHASA MENYIMPANG}

Batasan dan jenis-jenis perilaku bahasa menyimpang yang ditulis oleh para ahli psikolinguistik walaupun agak beragam tetapi tetap mengarah pada permasalahan yang sama yaitu ketidaknormalan dalam berbahasa dan sebab-sebab yang sama yaitu faktor psikologis dan fisiologis. Misalnya, Mukalel mengatakan bahwa ketika akal pikiran atau badan (mental dan psikologi mekanisme kemampuan berbicara) sebagai prinsip koordinasi aktivitas bahasa tidak berfungsi secara sempurna, hasilnya adalah perilaku bahasa menyimpang. ${ }^{13}$ Bayles \& Kaszniak mendefinisikan bahwa perilaku bahasa menyimpang adalah jenis kelainan dan gangguan pada seseorang untuk melakukan komunikasi secara normal. ${ }^{14}$ Caplan dan Curtiss memberikan definisi yang sama tentang perilaku bahasa menyimpang yaitu ketidakmampuan individu untuk menghasilkan bahasa normal disebabkan oleh kelainan fisik dan psikis. ${ }^{15}$ Yang dimaksud dengan bahasa normal menurut Curtiss adalah bahasa yang dihasilkan oleh orang yang tidak mengalami gangguan mental atau kelainan pada alat-alat produksi ujaran. Bahasa orang yang mengalami gangguan jiwa (gila) menurut Custiss kadangkadang bisa digolongkan pada perilaku bahasa menyimpang jika pasien suka berbicara sendiri (tanpa lawan bicara) atau suka berbicara sembarangan tanpa arah. ${ }^{16}$

Sementara itu, Code menulis bahwa orang sering mengacaukan antara kelainan bicara dan kelainan bahasa, pada hal dua istilah ini sesungguhnya memiliki makna yang berbeda. Kelainan bicara merujuk pada masalah dalam produksi ujaran atau masalah dengan kualitas suara; sedangkan kelainan bahasa biasanya menyangkut hambatan dalam memahami kata atau ketidakmampuan dalam menggunakan katakata yang tidak ada hubungannya dengan produksi ujaran. ${ }^{17}$ 


\section{JENIS-JENIS PERILAKU BAHASA MENYIMPANG}

Caplan menggolongkan kemampuan berbicara dalam kategori normal dan tidak normal (kelainan) merupakan masalah yang rumit sebab kenyataan menunjukkan bahwa hanya $5 \%$ hingga $10 \%$ dari populasi yang secara lengkap memiliki cara berbicara yang normal (dengan memperhatikan seluruh parameter) dan kesehatan suara; hampir tiap orang mengalami gangguan dalam berbicara. ${ }^{18}$ Dalam tulisannya, Caplan membagi jenis perilaku bahasa menyimpang dalam 8: (1) gagap (stuttering), (2) kekusutan (cluttering) (3) dysprosody, (4) kelainan bunyi ujaran (speech sound disorder), (5) kelaianan suara (voice disorder), (6) dysartria, (7) apraxia, dan (8) aphasia (afasia).

1. Gagap (stuttering)

Gagap adalah gangguan kelancaran atau abnormalitas dalam kecepatan atau irama bicara. Kelainan ini ada hubungannya dengan riwayat keluarga. Orang yang menderita gagap cenderung untuk mengulang-ulang bagian pertama dari kata (misalnya: mememememenyimpang) atau menahan bunyi tunggal dalam waktu yang lama (misalnya, mengganggu).

2. Kekusutan (cluttering)

Gejala ini merupakan masalah lain yang membuat pembicaraan seseorang sukar untuk dimengerti. Seperti halnya gagap, kekusutan mempengaruhi kelancaran, atau aliran pembicaraan seseorang. Akan tetapi perbedaannya adalah kekusutan (cluttering) adalah kelainan dalam berbahasa, sementara gagap adalah kelainan dalam berbicara. Orang yang gagap memiliki kesulitan untuk mengeluarkan apa yang mereka ingin katakan, dan orang yang menderita kekusutan mengatakan apa yang mereka pikirkan, tetapi menjadi tidak terorganisasi. Karena ketidakterorganisasian ini orang yang menderita kelainan ini akan berbicara meledak-ledak atau tiba-tiba berhenti, iramanya kacau dan pembicara tidak menyadari masalah ini.

3. Dysprosody

Dysprosody adalah gangguan bicara secara neorologis yang jarang terjadi. Gangguan ini ditandai dengan pergantian intensitas dalam segmen waktu dan ujaran, dan dalam irama dan intonasi kata. Penyebab dysprosody biasanya diasosiasikan dengan patologi neorologis misalnya rusaknya pembuluh darah pada otak karena kecelakaan, trauma, dan tumor otak.

4. Kelainan bunyi ujaran (speech sound disorder)

Kelainan ini berhubungan dengan kesulitan untuk menghasilkan bunyi-bunyi ujaran tertentu (lebih sering konsonan-konsonan tertentu, misalnya /s/ atau /r/), dan dibagi menjadi kelainan artikulasi (juga disebut kelainan fonetis) dan kelainan fonemik.

5. Kelainan suara (voice disorder)

Kelainan suara adalah gangguan atau kelainan secara fisik yang melibatkan fungsi anak tekak atau getaran suara.

6. Dysartria

Kelainan ini ditandai dengan melemahnya atau lumpuhnya otot-otot karena keru- 
sakan saraf dan/atau otak. Dysasthria disebabkan oleh penyakit stroke, parkinson, luka di leher atau kepala, atau kelumpuhan saraf.

7. Apraxia

Penyakit ini disebabkan oleh stroke, yaitu penderita tidak konsisten dalam menghasilkan bunyi dan cenderung untuk menyusun kembali bunyi-bunyi menjadi kata yang tidak bermakna atau menyimpang dari apa yang dimaksudkan (misalnya, kata "tikus" menjadi "tukis", "kepala" menjadi "kelapa", dsb).

8. Aphasia (afasia)

a. Afasia Broca merupakan istilah bagi orang yang menderita ketidakmampuan merencanakan rentetan motoris yang digunakan dalam berbicara. Misalnya, berbicara terpatah-patah, sulit mengeluarkan kata-kata, cenderung berbicara telegrafis (menghilangkan kata-kata fungsi dan afiks inflektif).

b. Afasia Wernicke adalah istilah yang ditujukan kepada orang yang kacau menerima pesan. Afasia ini bersifat reseptif, tidak sulit berbicara namun cenderung memakai bahasa yang secara semantis tidak koheren. ${ }^{19}$

Dalam sumber-sumber lain, Caplan dan Curtiss memerinci hanya empat jenis kelainan dalam berbicara, yaitu (1) gagap (stuttering); (2) kekusutan (cluttering); (3) kelainan artikulasi; dan (4) apraxia. ${ }^{20}$ Perbedaan ini mungkin saja terjadi karena tiga jenis kelainan lainnya yang belum tercakup oleh Curtiss merupakan jenis penyakit yang baru ditemukan dalam dunia kedokteran. Sementara itu, Dingwal memerinci 4 jenis kelainan berbicara yang lebih umum ditemukan yaitu (1) gagap; (2) kelainan artikulasi yaitu produksi suara yang tidak benar atau tidak tepat; (3) kelainan suara, yaitu abnormalitas kualitas suara, nada, dan keakrasaraan suara; (4) bisu, yaitu ketidakmampuan untuk menghailkan suara. ${ }^{21}$

Mukalel melihat perilaku bahasa menyimpang dari latar belakang fisiologis dan psikologis. Dari segi fisiologis Mukalel memaparkan beberapa penyebab kelainan ini, yaitu (1) cacat pada sistem saraf pusat; (2) cacat pada mekanisme vokal; dan (3) cacat pada mekanisme pendengaran. Sedangkan dari segi kelainan psikologis (psychogenic) bersumber dari akal pikiran. ${ }^{22}$

\section{PENYEBAB PERILAKU BAHASA MENYIMPANG}

Berbagai macam penyebab perilaku bahasa menyimpang yang lebih umum menurut Dingwal adalah gangguan mental. Penyebab-penyebab lainnya, (1) attention deficit disorder (ADD), (2) autisme, (3) Kelumpuhan saraf otak, (4) Cleft palate (celah langit-langit), (5) kelainan pada langit-langit, (6) Sindrom Cridu-chat23, (7) Sindrom Gilles de la Tourette24, (8) gangguan pendengaran, (9) Learning Disability, (10) Schizophrenia ${ }^{25}$, (11) luka pada pita suara ${ }^{26}$.

Menurut Mukalel bahwa perilaku bahasa menyimpang disebabkan oleh kelainan fisiologis, yaitu segala bentuk cacat mekanisme fisiologis perilaku bahasa yang dapat menyebabkan bahasa menyimpang dari segi pemahaman atau produksi. ${ }^{27}$ Berikut ini adalah beberapa bentuk kelainan dan penyimpangan yang dikemukakan oleh $\mathrm{Mu}-$ kalel ${ }^{28}$ yang secara umum dapat diamati: 


\section{Kerusakan pada Sistem Saraf Pusat}

Penyakit-penyakit tertentu, kelainan pertumbuhan dan kondisi biologis lainnya memengaruhi fungsi normal sistem saraf, dan menyebabkan kelainan perilaku termasuk kelainan perilaku bahasa. Gangguan pada otak atau saraf tulang belakang menyebabkan kehilangan fungsi bahasa secara total atau gangguan sebagian yang mengakibatkan (a) kelainan bawaan atau (b) gangguan fungsi saraf permanen atau sementara, menyebabkan kehilangan atau penyimpangan perilaku bahasa.

\section{Cacat Mekanisme Suara}

Selain gangguan kelainan pada otak, penyimpangan perilaku bahasa juga disebabkan oleh cacat pada mekanisme suara yang berperanan dalam produksi bahasa. Jika cacat atau kelainan otak dapat memengaruhi produksi dan pemahaman (penerimaan) bahasa, cacat pada bagian mekanisme suara akan mengakibatkan gangguan produksi ujaran.

\section{a. Paru-paru}

Paru-paru dikenal sebagai gelembung-gelembung fungsi bicara. Terbentuknya produksi ujaran tidak terlepas dari peranan napas yang berasal dari paru-paru. Ada beberapa jenis penyakit yang memengaruhi paru-paru. Volume udara yang masuk dan keluar dari paru-paru diistilahkan sebagai kapasitas vital paru-paru. Kapasitas vital ini dapat berkurang karena penyakit paru-paru, penyakit jantung dan karena lemahnya otot-otot yang berperanan dalam pernapasan. Hilangnya kapasitas vital ini dapat mempengaruhi produksi ujaran. Individu yang mengalami hal ini tidak akan dapat lagi memompa napas yang dibutuhkan untuk produksi ujaran. Ini akan mengakibatkan kesukaran, gangguan, dan ketidaklengkapan dalam berbicara. Penyimpangan perilaku seperti ini dapat diamati pada orang yang menderita TBC atau asma.

\section{b. Pita Suara}

Kerusakan pada lipatan horizontal pada tenggorokan atau tenggorokan secara keseluruhan (struktur yang menyerupai kotak dibelakang jakun) mengakibatkan gangguan bicara. Infeksi pada lipatan-lipatan suara ini akan menyebabkan gangguan bicara secara permanen atau sementara.

c. Lidah

Masalah lain yang dianggap hambatan dalam produksi ujaran adalah kelumpuhan lidah. Ujaran secara keseluruhan atau sebagian dipengaruhi oleh kerusakan pada lidah. Orang yang mengalami gangguan pada lidah ini sama sekali hampir tidak dapat menghasilkan ujaran (bisu). Berbeda dengan orang yang mengalami kerusakan paru-paru atau pita suara, sekurang-kurangnya masih bisa memproduksi ujaran dengan cara berbisik.

\section{Cacat Pendengaran}

Ada hubungan erat secara psikologis antara pendengaran dan artikulasi mekanisme ujaran. Anak-anak mulai mendengarkan rangsangan bahasa berbulan-bulan 
lebih awal sebelum menghasilkan bahasa. Menyimak dan mengingat dimulai lebih awal dalam kehidupan anak-anak. Fakta yang signifikan menunjukkan bahwa keseluruhan perilaku bahasa berawal dari pendengaran. Oleh karena itu kita dapat melihat anak-anak yang tuli sejak lahir tidak akan belajar bahasa sehingga kemampuan berbicaranya akan tertinggal. Kapasitas belajar bagi orang seperti ini akan tergantung pada indera visual (dan indera peraba bagi mereka yang buta dan tuli). Masalah pendengaran dapat disebabkan oleh lebih dari satu sebab, antara lain: (a) pasien mengalami afasia dapat mengalami kehilangan pendengaran karena afasia memengaruhi hampir keseluruhan aspek kapasitas berbicara, (b) mereka yang mengalami tuli sejak lahir, dan (c) kelainan pasca kelahiran yang menyebabkan hilangnya pendengaran secara parsial atau keseluruhan.

Pasien yang mengalami afasia menunjukkan, (1) ketidakmampuan mengingat makna kata-kata yang diucapkan (word-deftness), (2) ketidakmampuan mengenal kata disebabkan oleh ketidakmampuan membedakan bunyi, (3) ketidakmampuan memahami makna secara keseluruhan dari wacana, (4) ketidakmampuan mengingat kata untuk melengkapi kalimatnya, dan (5) kebingungan ketika mencoba mengekpresikan diri. Dalam beberapa kasus afasia, dilaporkan bahwa seorang pasien mengenal suara sebagai bunyi saja, tidak lebih dari itu dia mengenal bahasa, tapi tidak dapat mengenal apa yang dikatakan, dia mendengar suara dan dapat mengulanginya, tetapi tidak memahami apa yang dikatakannya.

Yang tergolong dalam gangguan bicara (penyimpangan bahasa) secara fisiologis termasuk cacat vokal dan mekanisme pendengaran. Selanjutnya, penting untuk membedakan penyimpangan bahasa secara fisiologis itu dengan penyimpangan yang secara langsung disebabkan oleh gangguan mental. Apa yang dapat diamati pada pasien patologi bahasa atau orang yang menderita gangguan bicara yaitu mereka tidak mampu secara normal menggunakan fungsi perilaku linguistik mereka, jika tidak secara total kehilangan fungsi ujaran itu. Gejala ini cukup jelas karena kemampuan berbicara secara eksternal dapat dimati dengan jelas.

Dalam beberapa kasus, sukar untuk membedakan antara penyimpangan kemampuan berbicara yang disebabkan oleh faktor fisiologis dan psikologis. Hal ini benar khususnya jika gangguan fisologis disebabkan oleh kelainan otak atau masalah fisiologis lainnya yang tidak dapat didiagnosis dengan mudah. Petunjuk utama dalam masalah ini dapat berupa adanya atau ketiadaan gejala yang dapat dideteksi yang menyertai gangguan (kelainan) dalam berbicara. Ketika gejala kelainan fisiogenik muncul, maka untuk menjajaki kelainan dalam berbicara akan sukar karena kelainan itu mungkin saja disebabkan oleh cacat fisiologis atau secara langsung karena kelainan pada akal pikiran. Akan tetapi, sumber kelainan sangat signifikan dari sudut pandang langkah-langkah terapi. Gangguan fisiogenik, menurut Mukalel dapat memengaruhi kemampuan berbicara sebagian besar berasal dari kelainan otak. ${ }^{29} \mathrm{Di}$ antara kelainan-kelainan itu adalah sebagai berikut:

1. Infeksi otak yang disebabkan oleh virus dan bakteri.

2. Tumor otak yang menyebabkan pembesaran pada jaringan saraf. 
3. Luka di kepala yang sering menyebabkan gangguan otak dan mempengaruhi fungsi normal otak.

4. Gangguan metabolisme yang secara langsung memengaruhi fungsi neurologis, misalnya, kekurangan nutrisi yang menyebabkan ketidakseimbangan fungsi kelenjar endokrin.

5. Epilepsi sebagai gangguan dalam sistem saraf.

6. Penyakit pikun yang disebabkan oleh menurunnya fungsi saraf karena faktor ketuaan.

Dari gangguan fisiogenis yang memengaruhi akal pikiran dan akhirnya perila$\mathrm{ku}$ bahasa, dapat dibedakan kelainan-kelainan itu yang secara langsung berasal dari akal pikiran, mempengaruhi dan mengacaukan akal pikiran normal. Ketidaknormalan dan gangguan yang bersumber dari akal pikiran disebut kelainan psikogenik. ${ }^{30}$ Berikut beberapa kelainan utama yang berasal dari faktor psikologis.

1. Reaksi trauma terhadap perang sebagai akibat dari pengalaman pertempuran militer yang dahsyat. Kelainan ini bisa bersifat neorotic sementara atau permanen atau reaksi psychotic, yang terjadi karena situasi peperangan, kelelahan fisik, ancaman kematian atau mutilasi dan goncangan psikologis.

2. Reaksi trauma terhadap bencana, misalnya kecelakaan pesawat, terperangkap dalam gedung yang terbakar, kecelakaan lalulintas, ledakan, banjir, gempa bumi, dll. Telah menjadikan orang dengan gangguan kepribadian sebagai akibat pengalaman buruk yang mereka alami.

3. Perasan tertekan (stress) sebagai reaksi atas perasaan terancam, takut, atau ketidakpuasan terhadap hal-hal tertentu.

4. Gangguan psychoneurotic ditemukan pada mereka yang mengalami cacat perkembangan biologis, psikologis, atau sosiologis.

5. Gangguan psychophysiologic sebagai akibat dari ketegangan emosi yang yang kronis.

6. Gangguan psychotic berasal dari situasi stres secara psikologis, gangguan organ otak atau inteaksi dari keduanya.

Hampir sama dengan Mukalel, Goldstein memerinci kelainan bahasa yang disebabkan oleh faktor psikologis yaitu, (1) sebagai akibat trauma, (2) karena perasaan tertekan (stress), dan (3) emosi yang tidak terkendalikan. ${ }^{31}$

Selanjutnya, Mukalel menyatakan bahwa bidang-bidang aktivitas bahasa yang dipengaruhi oleh kelainan psychogenic adalah:

1. Hilangnya aktivitas berbicara sebagai akibat dari gangguan otak kronis dan serangan epilepsi atau reaksi trauma yang sangat akut terhadap perang atau bencana alam.

2. Kurangnya organisasi konseptual sebagai akibat dari gangguan psikogenik.

3. Kurangnya pemahaman yang diakibatkan oleh masalah-masalah gangguan psikologis.

4. Kehilangan memory adalah jenis lain dari gangguan psikogenik.

5. Kerusakan pendengaran yang biasa dialami oleh pasien dengan gangguan psycho- 
physiologis yang mempengaruhi otak atau organ pendengaran.

6. Kerusakan fungsi penglihatan yang terjadi pada penderita kelainan psychogenic.

7. Kelainan fungsi sensory motor adalah bidang lain yang merupakan manifestasi kelainan dalam berbicara. Pasien yang menderita gangguan psychogenic sering lidah mereka tidak dapat untuk memproduksi ujaran atau ujaran menjadi sulit, lambat dan tersentak-sentak. Artikulasi untuk bunyi-bunyi tertentu menjadi sukar; kelancaran dalam berbicara berada di luar jangkauan pasien. ${ }^{32}$

Manifestasi kelainan psychogenic dalam aktivitas bahasa terjadi dalam bidang sintaksis, semantik, dan artikulasi. Kesalahan artikulasi, kesalahan sintaksis organisasi kalimat, dan kesalahan dalam organisasi makna terjadi ketika pasien menderita kelainan psikologis yang mencoba untuk berbicara, membaca, atau menulis. Sebagaimana dalam kasus afasia, pasien yang mengalami gangguan saraf atau psikologis mengalami masalah dalam hal pemahaman dan produksi bahasa. Demikian pula dalam aspek-aspek bahasa seperti dalam produksi bunyi (artikulasi), organisasi sintaksis, dan konfigurasi semantik yang dibutuhkan untuk komunikasi lisan dan tulisan.

Penulis lain, Blager BF dalam Goldstein ${ }^{33}$ memaparkan sebab-sebab gangguan bicara dan efek pada perkembangan bicara seperti disajikan dalam tabel berikut:

Tabel 1.

Sebab-sebab Gangguan dan Efek pada Perkembangan Bicara

\begin{tabular}{|c|c|}
\hline Penyebab & Efek pada Perkembangan Bicara Anak \\
\hline $\begin{array}{l}\text { Lingkungan } \\
\text { a. Sosial ekonomi (kurang) } \\
\text { b. Tekanan keluarga } \\
\text { c. Keluarga bisu } \\
\text { d. Pemakaian bahasa bilingual }\end{array}$ & $\begin{array}{l}\text { a. Terlambat } \\
\text { b. Gagap } \\
\text { c. Terlambat pemerolehan bahasa } \\
\text { d. Terlambat pemerolehan struktur bahasa }\end{array}$ \\
\hline $\begin{array}{l}\text { Emosi } \\
\text { a. Ibu yang tertekan } \\
\text { b. Gangguan serius pada orang } \\
\text { tua } \\
\text { c. Gangguan serius pada anak }\end{array}$ & $\begin{array}{l}\text { a. Terlambat pemerolehan bahasa } \\
\text { b. Terlambat atau gangguan perkembangan } \\
\text { bahasa } \\
\text { c. Terlambat atau gangguan perkembangan } \\
\text { bahasa }\end{array}$ \\
\hline $\begin{array}{l}\text { 3. Masalah Pendengaran } \\
\text { a. Kongenital } \\
\text { b. Didapat }\end{array}$ & $\begin{array}{l}\text { a. Terlambat atau gangguan bicara permanen } \\
\text { b. Terlambat atau gangguan bicara permanen }\end{array}$ \\
\hline $\begin{array}{l}\text { 4. Perkembangan terlambat } \\
\text { a. Perkembangan lambat } \\
\text { b. Retardasi mental }\end{array}$ & $\begin{array}{l}\text { a. Terlambat bicara } \\
\text { b. Pasti terlambat bicara }\end{array}$ \\
\hline $\begin{array}{l}\text { 5. Cacat bawaan } \\
\text { a. Palatoschiziz } \\
\text { b. Sindrom down }\end{array}$ & $\begin{array}{l}\text { a. Terlambat dan terganggu kemampuan bicara } \\
\text { Kemampuan bicara lebih rendah }\end{array}$ \\
\hline
\end{tabular}


6. Kerusakan Otak

a. Kelainan neoro muskular

b. Kelainan sensori motor

c. Palsi selebral

d. Kelainan persepsi a. Mempengaruhi kemampuan menghisap, dan menelan, mengunyah, dan akhirnya timbul gangguan bicara dan artikulasi seperti disastria

b. Mempengaruhi kemampuan menghisap, menelan, akhirnya menimbulkan gangguan artikulasi, seperti dispraksia

c. Berpengaruh pada pernapasan, makan, dan timbul juga masalah artikulasi yang mengakibatkan disartria dan dispraksia

d. Kesulitan membedakan suara, mengerti bahasa, simbolisasi, mengenal konsep, akhirnya menimbulkan kesulitan belajar di sekolah.

\section{PERILAKU BAHASA MENYIMPANG DAN LINGKUNGAN RUMAH}

Ada aspek lain penyimpangan bahasa yang membutuhkan perhatian dalam konteks ini, yaitu jenis penyimpangan sebagai karakteristik pembelajaran bahasa pertama di rumah dan pembelajaran bahasa kedua di kelas. Mungkin akan muncul pertanyaan sehubungan dengan penamaan bahasa anak dengan kesalahbiasaan sebagai penyimpangan bahasa. Jawabannya adalah jelas bahwa segala bentuk aktivitas bahasa (apakah dari sudut pandang isi atau fungsional) yang menyimpang dari perilaku bahasa normal merupakan bagian dari perilaku bahasa menyimpang.

Rumah sebagai benteng perkembangan bahasa juga menyajikan pada kita berbagai macam kasus kelainan bahasa. Kategori utama penyimpangan bahasa dalam hubungannya dengan lingkungan rumah seperti diuraikan oleh Mukalel adalah (1) penyimpangan bahasa yang terbentuk sebagai bagian dari perkembangan normal bahasa anak, dan (2) kelainan bahasa sebagai akibat dari gangguan psychogenic atau physiogenic. ${ }^{34}$

Masalah perilaku penyimpangan bahasa pada anak-anak sangat beragam dan tumpang tindih. Pertama, berhubungan dengan perilaku bahasa menyimpang dari anak-anak yang normal yang tidak mengalami masalah perkembangan yang menyolok. Berikut merupakan masalah anak dengan perkembangan normal yang dikutip dari Mukalel: ${ }^{35}$

Keterlambatan dalam berbicara yang disebabkan oleh (1) faktor sosiologis misalnya sikap orang tua; (2) hubungan anak dengan anak-anak lain dalam keluarga; (3) kurangnya motivasi yag cukup; (4) isolasi dari anak-anak lain; (5) sedikit gangguan kepribadian yang disebabkan latar belakang sosiologis atau biologis.

\section{Cacat Artikulasi}

Cacat artikulasi bagi anak-anak dalam berbicara merupakan sesuatu yang dapat diamati di rumah. Cacat artikulasi bersifat lumrah dan merupakan tonggak perkembangan bahasa yang normal. Cacat artikulasi tidak hanya terbatas pada anak-anak di bawah umur, tetapi lebih umum bahkan terjadi juga pada anak-anak usia sekolah 
yang mengalami perilaku bahasa menyimpang. Cacat dalam artikulasi tanpa unsur gagap seperti itu dianggap universal dalam anak-anak normal. Cacat dalam artikulasi tanpa gangguan fisiologis merupakan akibat dari:

1. Kurang perhatian orang tua dalam memberikan koreksi tepat waktu,

2. Keterisolasian, di mana anak-anak dibesarkan tanpa ada kesempatan untuk bergaul dengan anak-anak lain, dan

3. Penguatan orang tua yang salah, yang diberikan kepada anak dengan selalu mengulangi ucapan-ucapan anak yang salah (sehingga anak hampir tidak mendapat kesempatan untuk membedakan ucapan yang salah dan benar).

4. Keterlambatan dalam berbicara sehingga artikulasi cacat sebagian, misalnya: a). Ibuku memacak lawon (memasak rawon) b. Anjing gogong (menggonggong).

Cacat artikulasi lebih mempengaruhi bunyi-bunyi konsonan daripada vokal karena dalam produksi konsonan melibatkan individual artikulator sehingga kontrol sensory motor dibutuhkan.

\section{Penyimpangan Sintaktis}

Meliputi penempatan yang salah dari kata benda dan kata kerja, serta penggunaan kata kerja transitif tanpa objek. Kesalahan dalam sintaksis dianggap sebagai bagian dari kelainan dalam bahasa jika berlanjut pada usia yang seharusnya kebiasaan ini sudah hilang.

\section{Cacat Semantik}

Bidang utama penyimpangan bahasa pada anak-anak adalah organisasi makna dalam pembentukan kalimat. Dengan alasan keterbatasan kosa-kata pada anak-anak seperti itu kalimat yang mereka bentuk cenderung membingungkan.

\section{Fragmentasi Kalimat}

Fragmentasi dan ketidaksambungan kalimat sebagai bagian dari kelainan dalam bahasa, akan tetapi sesungguhnya terjadi juga pada anak-anak normal. Yang tidak diragukan lagi untuk dikelompokkan sebagai anak-anak yang tidak normal dengan ciri kelainan fisiologis atau psikogenik. Yang termasuk kategori itu menurut Mukalel adalah (1) anak-anak yang mengalami keterbelakangan mental, (2) anakanak dengan perkembangan otak yang abnormal, (3) tuli, dan (4) anak-anak yang mengalami cacat organ wicara. ${ }^{36}$

\section{KELAINAN BAHASA DAN SEKOLAH}

Sekolah sebagai perluasan rumah tempat tinggal dan masalah belajar bahasa pertama di rumah berlanjut hingga di ruang kelas. Ketika anak-anak berangkat dari rumah ke sekolah, pengalaman pembelajaran bahasa mendapatkan dimensi baru, yaitu pembelajaran bahasanya terjadi dalam rangkaian kognitif dan faktor sosial dan pengalaman yang berbeda. Penyesuaian dan asimilasi yang berhasil terhadap faktor kognitif dan sosiologis ini membutuhkan kepribadian yang seimbang dan normal tanpa tumpang tindih secara psikologis dan fisiologis.

Mukalel mengelompokkan tiga kategori pembelajaran di kelas: pembelajar cerdas, pembelajar rata-rata, dan pembelajaran lambat. Dalam batasan penyesuaian 
diri kategori ini masih dibagi dalam sub-kelompok: pembelajar cerdas yang termotivasi, pembelajar rata-rata dan pembelajar lambat, serta pembelajaran cedas yang tidak termotivasi, pembelajar rata-rata dan pembelajar lambat. Secara kognitif, sosiologis dan linguistik yang lebih menguntungkan adalah pembelajar cerdas yang termotivasi dan yang tidak menguntungkan adalah pembelajar lambat yang tidak termotivasi. Pembelajar dapat dikelompokkan dan didistribusi berdasarkan penggolongan ini. ${ }^{37}$

Prestasi linguistik bersama-sama dengan pengalaman kognitif dan penyesuaian sosiologis muncul sebagai komponen utama pretasi anak di sekolah. Dalam hal inilah perilaku bahasa menyimpang menjadi signifikan dalam kehidupan sekolah anakanak. Anak dengan masalah perilaku bahasa mungkin merupakan bagian dari salah satu kelompok yang disebutkan di atas. Namun, keberhasilan atau ketidakmampuan menyesuaikan diri dari pembelajar tertentu yang memiliki kelainan dalam berbicara akan tergantung pada kelompok atau sub-kelompok mana pembelajar itu berada.

Segala bentuk kelainan dalam berbicara dan seluruh tingkat kelainannya tidak akan terpisahkan dari ruangan kelas seperti biasanya. Kelas biasa sebagaimana yang ada di sekolah-sekolah kita, ditujukan khusus untuk mereka yang secara psikologis dan mental cukup sehat dan normal untuk menyesuaikan diri dalam pola-pola dan keadaan kelas setiap hari. Sehingga masalah kelainan misalnya gangguan mental, anak-anak yang menderita penyakit otak yang knonis, tuli dan sebagainya, tidak harus terlibat dalam situasi kelas pada umumnya. Anak-anak yang mengalami gangguan mental dan tuli menerima pendidikan yang terpisah dalam situasi yang sesuai dengan kebutuhan unik mereka yang tidak dapat diperoleh pada situasi kelas biasa.

Akibatnya, kelainan bicara sebagai faktor linguistik yang relevan dengan pembelajaran kelas sejauh ini hanya beberapa masalah kelainan unik. Akan tetapi, masalah-masalah yang dihadapi anak sekolah ini berpengaruh terhadap keberhasilan. Ada beberapa kelainan unik yang sering ditemukan khususnya pada tahun-tahun awal ketika anak masuk sekolah. Masalah seperti itu sering diabaikan oleh guru pada umumnya yang memiliki masalah pengajaran yang harus diselesaikan dan cenderung mengabaikannya ketika terdapat anak-anak yang mengalami kelainan berbahasa. Mukalel memaparkan jenis-jenis perilaku penyimpangan bahasa yang dialami oleh anak-anak sekolah ${ }^{38}$.

1. Kelainan pendengaran

Kelainan pendengaran mulai dari kesulitan untuk memahami sesuatu yang diucapkan guru hingga kesulitan untuk mengenal kata-kata yang diucapkan guru khususnya apabila posisi guru tidak secara langsung menghadap anak-anak.

2. Masalah pengucapan

Masalah-masalah produksi ujaran yang disebabkan oleh cacat organ artikulasi atau titik artikulasi merupakan masalah perilaku bahasa menyimpang bagi anakanak di sekolah

3. Gangguan visual

Anak-anak yang mengalami gangguan visual dapat dilihat ketika mereka diminta untuk membaca dengan keras. 


\section{Gangguan gerak (motor)}

Masalah dengan kontrol gerak vokal anak-anak dan berhubungan dengan organorgan dapat menyebabkan gangguan dalam berbicara. Fenomena ini dapat juga terjadi di ruangan kelas.

Anak-anak dengan kasus kelainan bicara merupakan kasus yang tidak terpisahkan dengan pembelajaran di sekolah, khususnya prasekolah dan sekolah dasar. Orang tua di perkotaan terkadang menyadari kalau anaknya mengalami kelainan dalam bicara, akan tetapi merasa malu untuk menitipkan anaknya di sekolah khusus (misalnya, SLB), merasa malu jika diketahui ia memiliki anak yang kurang normal sehingga dipaksakan untuk masuk di sekolah umum, demikian juga di daerah-daerah pedesaan yang memang belum ada SLB, maka anak-anak seperti ini yang seharusnya mendapat perlakuan khusus terpaksa diperlakukan sama saja dengan anakanak lain yang tidak bermasalah.

\section{SIMPULAN}

Kemampuan berbahasa seseorang dipengaruhi oleh faktor psikis (kejiwaan) dan faktor fisik. Bila seseorang mengalami gangguan fisik atau kelainan pada organorgan artikulasi dan otak atau gangguan psikis maka dapat dipastikan tidak akan menghasilkan bahasa yang normal karena bahasa merupakan hasil dari koordinasi fungsi akal pikiran manusia dan mekanisme fisiologis. Ketika prinsip-prinsip koordinasi antara akal pikiran dan mekanisme fisiologis tidak berfungsi secara sempurna maka terjadilah penyimpangan dalam bahasa.

Rumah sebagai awal perkembangan bahasa juga menyajikan berbagai macam kasus kelainan bahasa. Kategori utama penyimpangan bahasa dalam hubungannya dengan lingkungan rumah adalah: (1) penyimpangan bahasa yang terbentuk sebagai bagian dari perkembangan normal bahasa anak, dan (2) kelainan bahasa sebagai akibat dari gangguan psychogenic atau physiogenic.

Perilaku bahasa menyimpang menjadi signifikan dalam kehidupan sekolah anak-anak. Segala bentuk kelainan dalam berbicara dan seluruh tingkat kelainannya tidak akan terpisahkan dari ruangan kelas. Kelas biasa sebagaimana yang ada di sekolah-sekolah pada umumnya ditujukan khusus untuk mereka yang secara psikologis dan mental cukup sehat dan normal untuk menyesuaikan diri dalam polapola dan keadaan kelas setiap hari. Sehingga masalah kelainan misalnya gangguan mental, anak-anak yang menderita penyakit otak yang knonis, tuli dan sebagainya, semestinya tidak harus terlibat dalam situasi kelas pada umumnya. Anak-anak yang mengalami gangguan mental dan tuli seharusnya menerima pendidikan yang terpisah dalam situasi yang sesuai dengan kebutuhan unik mereka, yang tidak dapat diperoleh pada situasi kelas biasa.

\section{CATATAN AKHIR}

1. D. Caplan, Neorolinguistics and Linguistics Aphasiology, An Introduction. New York: Cambridge University Press, 2001. 
2. K. Bayles, \& A. Kaszniak, Comunication and Cognition in Normal Aging and Dementia, Boston: College-Hill, 2006, h. 221.

3. Joseph C. Mukalel, Psychology of Language Learning, New Delhi: Discovery Publishing House, 2003, h. 146.

4. Ibid, h. 146.

5. K. Bayles, \& A. Kaszniak, op.cit.

6. D. Caplan, op.cit., h. 116.

7. Ibid, h. 116.

8. Joseph C. Mukalel, op. cit., dan W. Dingwall, Language and the Brain: A Bibliography and Guide, New York: Garland, 2000.

9. Joseph C. Mukalel, ibid., dan Dingwall. W. 2000. ibid.

10. K. Goldstein, Language and Language Disturbance, New York: Grune and Straton, 2003, h. 213.

11. Joseph C. Mukalel, op. cit.,

12. Ibid.

13. Ibid., h. 147.

14. K. Bayles, \& A. Kaszniak, op.cit.

15. D. Caplan, Language: Structure, Processing and Disoders. Cambridge, MA: MIT Press, 1999. dan S. Curtiss, Genie: A Psycholinguistics Study of a Modern-Day "Wild Child". New York: Academi Press, 1994.

16. S. Curtiss, ibid., h. 117.

17. C. Code, Language, Aphasia, and the Right Hemisphere, New York: Wiley, 2005, h. 114

18. D. Caplan, op.cit., h. 67.

19. ibid., h. 116.

20. ibid., dan S. Curtiss, op.cit.

21. W. Dingwall, op. cit., h. 201.

22. Joseph C. Mukalel, op. cit.

23. Disebabkan oleh hilangnya kromosom 5, anak-anak dengan kondisi ini sering memiliki tangisan dengan suara tinggi yang berbunyi seperti suara kucing.

24. Kelainan sistem saraf yang menyebabkan orang melakukan perulangan gerakan (involuntary) dan suara (vocalization) yang tidak terkendali.

25. Kelainan otak yang kronis, parah dan membuatnya tidak berfungsi. Penderita dapat mendengar suara yang tidak didengar orang lain, percaya bahwa orang lain dapat membaca dan mengendalikan pikiran mereka atau berencana menyakiti mereka.

26. W. Dingwall, op. cit., h. 205.

27. Joseph C. Mukalel, op. cit.

28. Ibid.,

29. Ibid.

30. Ibid.

31. K. Goldstein, op. cit.

32. Joseph C. Mukalel, op. cit.

33. K. Goldstein, op. cit. h. 203.

34. Joseph C. Mukalel, op. cit. h. 160.

35. Ibid.

36. Ibid.

37. Ibid.

38. Ibid., h. 167. 


\section{DAFTAR PUSTAKA}

Bayles, K., \& Kaszniak, A., Comunication and Cognition in Normal Aging and Dementia, Boston: College-Hill, 2006.

Caplan, D., Neorolinguistics and Linguistics Aphasiology; An Introduction, New York: Cambridge University Press, 2001.

Caplan, D., Language: Structure, Processing and Disoders, Cambridge, MA: MIT Press, 1999.

Code, C., Language, Aphasia, and the Right Hemisphere, New York: Wiley, 2005.

Curtiss, S., Genie: A Psycholinguistics Study of a Modern-Day "Wild Child", New York: Academi Press, 1994

Dingwall. W., Language and the Brain: A Bibliography and Guide, New York: Garland, 2000.

Goldstein, K., Language and Language Disturbance, New York: Grune and Straton, 2003.

Mukalel, Joseph C., Psychology of Language Learning, New Delhi: Discovery Publishing House, 2003. 